Creative commons User License: CC BY-NC-ND

Abstracted by: EBSCOhost, Electronic Journals Service (EJS),

Google Scholar, Directory of Open Access Journals (DOAJ),

Journal Seek, Scientific Commons,

Food and Agricultural Organization (FAO), CABI and Scopus
Journal of Agricultural Extension

Vol. XX (X) XXXXXX, 20XX

ISSN(e): 24086851; ISSN(Print); 1119944X

http://journal.aesonnigeria.org

http://www.ajol.info/index.php/jae

Email: editorinchief@aesonnigeria.org

\title{
Determinants of Participation in Youth-in-Agriculture Programme in Ondo \\ State, Nigeria \\ http://dx.doi.org/10.4314/jae.v20i2.8
}

\section{Thomas Kehinde Adesina}

Department of Agricultural Extension and Rural Development,

Faculty of Agriculture and Forestry

University of Ibadan,

Ibadan, Nigeria

Email: kehindeadesina@yahoo.com

Phone: 08055951145

\section{Eforuoku Favour}

Department of Agricultural Extension and Rural Development,

Faculty of Agriculture and Forestry

University of Ibadan,

Ibadan, Nigeria

Email: favouriteeforuoku@gmail.com

Phone: 08065193845

\begin{abstract}
The study examined the determinants of participation in Youth-In-Agriculture Programme (YIAP) in Ondo state, Nigeria. Multistage sampling procedure was used to draw 128 youths as study sample. Questionnaire was used to elicit information from the respondents. Data were analyzed with descriptive and inferential statistical tools: Chi-square, Pearson Product Moment Correlation and Multiple Linear Regression. Respondents' mean age was $32.0 \pm 5.1$ years; $59.4 \%$ were males, $99.2 \%$ had formal education and $62.2 \%$ were married. Mean households' size was $4 \pm 1.0$ persons. Over $50.8 \%$ had between 1 and 5 years farming experience. Most (68.0\%) had favourable attitude towards YIAP. Inadequate training facilities was the most severe constraint to participation (0.98) and participation in YIAP was above average (57.0\%). Predictors significantly related to YIAP participation were household size $(\beta=0.133, p=0.032)$, farm size $(\beta=0.373, p=0.001)$, years of farming experience $(\beta=0.354, p=0.002)$, attitude $(\beta=0.228, p=0.006)$ and constraints $(\beta=-0.074, p=0.032)$. However, farm size $(\beta=0.40)$ and years of participation $(\beta=0.36)$ mostly contributed to participation in YIAP. Effort by relevant agencies to providing extension education, encourage female youth participation and harnessing youth involvement in agriculture programme will ultimately reduce rural-urban drift.
\end{abstract}

Key words: Youth participation, Youth- in- Agriculture Programme, Drift, Employment 
Creative commons User License: CC BY-NC-ND

Abstracted by: EBSCOhost, Electronic Journals Service (EJS),

Google Scholar, Directory of Open Access Journals (DOAJ),

Journal Seek, Scientific Commons,

Food and Agricultural Organization (FAO), CABI and Scopus
Journal of Agricultural Extension

Vol. XX (X) XXXXXX, 20XX

ISSN(e): 24086851; ISSN(Print); 1119944X

http://journal.aesonnigeria.org

http://www.ajol.info/index.php/jae

Email: editorinchief@aesonnigeria.org

\section{Introduction}

Agriculture is one of the most viable sectors particularly in terms of its employment potentials. It is the foundation for the development of stable human communities, both in rural and urban communities. It provides environmental benefits such as, conservation, guaranteed sustainable management of renewable natural resources and preserved biodiversity (Preshstore, 2013). The agricultural sector is strategically positioned to have a high multiplier and linkage effect on any nation's quest for socioeconomic and industrial development. Unfortunately, Nigeria's agricultural sector is bedeviled with several challenges such as lack of access to markets and credits, low level of technology especially mechanization, inadequate post-harvest infrastructure (storage, processing, transport), low uptake of research findings by stakeholders and limited availability of improved technological packages especially planting materials and certified seeds (Ministry of Agriculture, 2007). This has made agriculture unattractive and non-lucrative resulting in decline in the number of youth participation in agriculture (Muhammad-lawal, Omotoesho and Falola, 2009). According to Aphunu andAtoma (2010), in Nigeria, farming population is aging. It is practically impossible for this aged generation dominating agricultural sector to deliver the expected productivity to meet food needs of the ever growing population.

Agriculture has huge and diverse opportunities potentials that can not only transform the national economy but also tremendously impact the personal lives of the farmers particularly the youth. Ovwigho and Ifie (2009) posited that Nigeria youths have the potentials to promote agriculture but most of them are not interested in agricultural activities. Hence, the federal government of Nigeria in an attempt to alleviate these problems came up with different policies and programmes to enhance involvement of youths in agriculture. One of such programmes is the Youth in Agriculture Programme (YIAP) introduced in 2004 as a subset of Agricultural Development Programme by the Ondo State Government and supported by World Bank. The objective of the programme was to create employment for the youth through active participation in modern agricultural practices by raising the production efficiency and productivity of the participants thereby taking up farming as a life time vocation. Although, YIAP in Ondo State has been transformed to programmes such as, Wealth 
Creative commons User License: CC BY-NC-ND

Abstracted by: EBSCOhost, Electronic Journals Service (EJS),

Google Scholar, Directory of Open Access Journals (DOAJ),

Journal Seek, Scientific Commons,

Food and Agricultural Organization (FAO), CABI and Scopus
Journal of Agricultural Extension

Vol. XX (X) XXXXXX, 20XX

ISSN(e): 24086851; ISSN(Print); 1119944X

http://journal.aesonnigeria.org

http://www.ajol.info/index.php/jae

Email: editorinchief@aesonnigeria.org

Creation Agency (WECA) and New Generation Farmers (NGF), they still maintain same objective of encouraging youth participation in agriculture thereby solving the problem of unemployment among the youths.

Participation is an obvious strategy for the success of any development project. It is a powerful tool for mobilizing new and additional resources. According to Ataneh (2012) participation entails the ability of individuals to have an input in the decision making process and to play a role in measures aimed at improving their quality of life. However, despite the perceived success of this programme the drift of youths from farming to less tedious and more lucrative jobs are on the rise, which creates the need to ascertain the level of participation and identify the determinants of participation in the programme. Furthermore, if agricultural extension is to be repositioned for effective agricultural economic development there is need to identify predictors for youth participation in order to increase youth participation in agricultural programmes.

Several studies have reported youth participation in agriculture. Muhammad-lawal, et al (2009) reported technical efficiency of youth participation in agriculture in Ondo State, Nigeria, Nnadi and Akwiwu (2008) assessed determinants of youths participation in rural agriculture in Imo State, Nigeria. While Ogunremi, Ogunremi and Faleyimu (2012) investigated relevance and benefits of agricultural youth empowerment programme to participating youth in Osun State. However, no study has identified the factors influencing participation of youths in agricultural programmes using YIAP in Ondo state as a case study.

The main objective of the study was to identify determinants of participation in YIAP with particular highlights on the socio-economic characteristics of the participants; attitudes of participants towards the YIAP; constraints to participation in YIAP and level of participation in YIAP.

\section{Methodology}

The study was carried out in Ondo State. Ondo state is located in the southwest geopolitical zone of the country. Its capital town is Akure. Ondo state has eighteen local government areas, the major towns include Akoko, Akure, Owo, Ondo, Okitipupa. Agriculture (including fishing) constitute the main occupation of the people 
Creative commons User License: CC BY-NC-ND

Abstracted by: EBSCOhost, Electronic Journals Service (EJS),

Google Scholar, Directory of Open Access Journals (DOAJ),

Journal Seek, Scientific Commons,

Food and Agricultural Organization (FAO), CABI and Scopus
Journal of Agricultural Extension

Vol. XX (X) XXXXXX, 20XX

ISSN(e): 24086851; ISSN(Print); 1119944X

http://journal.aesonnigeria.org

http://www.ajol.info/index.php/jae

Email: editorinchief@aesonnigeria.org

of the state producing both cash and food crops. The main revenue yielding crops are cocoa, palm produce and timber. Tree crops grown include, Kola, rubber, coffee, oilpalm. Arable crops like rice, cassava, maize, yam, pepper, beans, fruits, tomatoes and other vegetables are cultivated.

The population for the study is made up of youths in Ondo State who participated in youth in agriculture programme. The summary of sampling procedure is shown in Table 1. Multi-stage sampling procedure was used in selecting respondents for the study. Ondo State has 18 local governments areas. Ondo West, Ileoluji/Okeigbo and Ondo East Local Governments Areas were purposively selected because they were local governments having YIAP. In the selected local government areas, the two villages were YIAP have centres were purposively selected.Using the list of participants obtained from the centre, simple random sampling was used to select $30 \%$ of participants from each centre to give a sample size of 128 youths.

Table 1: Sampling procedures and sample size

\begin{tabular}{|c|c|c|c|c|}
\hline $\begin{array}{l}\text { Number } \\
\text { oflocal } \\
\text { governments } \\
\text { areas }\end{array}$ & $\begin{array}{l}\text { Selected local } \\
\text { governments } \\
\text { areas }\end{array}$ & $\begin{array}{l}\text { Selected } \\
\text { Villages }\end{array}$ & $\begin{array}{l}\text { Number of } \\
\text { participants }\end{array}$ & $\begin{array}{l}\text { Number of } \\
\text { respondents } \\
\text { randomly sampled } \\
(30 \%)\end{array}$ \\
\hline \multirow{6}{*}{18} & Ondo West & Asejere & 122 & 37 \\
\hline & & Irewunmi & 91 & 28 \\
\hline & Ile-Oluji & Bolorunduro & 50 & 15 \\
\hline & /Okeigbo & Akinboyewa & 50 & 15 \\
\hline & Ondo East & Epe & 60 & 18 \\
\hline & & Legiri & 50 & 15 \\
\hline Total & 3 & 6 & 423 & 128 \\
\hline
\end{tabular}

Validated questionnaire was used to elicit information. Pre-test was carried out in Odigbo Local Government Area of Ondo State. The data collected were analyzed with the aid of descriptive statistical tools such as frequency, percentage; mean and standard deviation were used. Inferential analysis such as Person Product Moment Correlation (PPMC), Chi-square relationship between the independent to the dependent variable and multiple linear regression analysis was used to determine youths' participation in YIAP in the study area. This is represented as:

$Y=a+\beta X_{1} \ldots \beta X_{12}$ where 
Creative commons User License: CC BY-NC-ND

Abstracted by: EBSCOhost, Electronic Journals Service (EJS),

Google Scholar, Directory of Open Access Journals (DOAJ),

Journal Seek, Scientific Commons,

Food and Agricultural Organization (FAO), CABI and Scopus
Journal of Agricultural Extension

Vol. XX (X) XXXXXX, 20XX

ISSN(e): 24086851; ISSN(Print); 1119944X

http://journal.aesonnigeria.org

http://www.ajol.info/index.php/jae

Email: editorinchief@aesonnigeria.org

$\mathrm{Y}=$ Participation in YIAP

$\mathrm{X}_{1}=$ age (years)

$\mathrm{X}_{2}=\operatorname{sex}($ Male $=1$, female $=0)$

$\mathrm{X}_{3}=$ marital status (married $=1$, unmarried $=0$ )

$\mathrm{X}_{4}=$ level of education (tertiary $=1$, non-tertiary $=0$ )

$X_{5}=$ household size

$\mathrm{X}_{6}=$ parents' occupation (farming related $=1$, non-farming $=0$ )

$\mathrm{X}_{7}=$ years of farming experience

$\mathrm{X}_{8}=$ farm size (hectares)

$\mathrm{X}_{9}=$ years of participation in YIAP

$\mathrm{X}_{10}=$ membership of youth association (member $=1$, non-member $=0$ )

$\mathrm{X}_{11}=$ attitude

$\mathrm{X}_{12}=$ constraints

\section{Results and Discussion}

\section{The socio-economic characteristics of participants}

The result on socioeconomic characteristics of respondents is presented on Table 2. It revealed that the age of the respondents ranged between 20 and 39 years, with a mean of 32.0 years, $35.2 \%$ of the respondents were between 30 and 34 years, $32.6 \%$ were between 35 and 39 years. This implies that most of the participants were matured and below 40 years of age. This is in-line with Muhammad-Lawal, et al (2009) who found that nature of the programme is specifically meant for the youth are for those below 40 years of age. Male respondents were $59.4 \%$, while females were $40.6 \%$. This suggests that males had higher participation than females in the programme which may be due to access to resources. This in tandem with Nnadi and Akwiwu (2008) that male had higher participation in agriculture programmes due to land ownership. 
Creative commons User License: CC BY-NC-ND

Abstracted by: EBSCOhost, Electronic Journals Service (EJS),

Google Scholar, Directory of Open Access Journals (DOAJ),

Journal Seek, Scientific Commons,

Food and Agricultural Organization (FAO), CABI and Scopus
Journal of Agricultural Extension

Vol. XX (X) XXXXXX, 20XX

ISSN(e): 24086851; ISSN(Print); 1119944X

http://journal.aesonnigeria.org

http://www.ajol.info/index.php/jae

Email: editorinchief@aesonnigeria.org

Table 2: Distribution of respondents by socio-economic characteristics

\begin{tabular}{|c|c|c|}
\hline Socio-economic characteristics & Percentage (\%) & Mean \\
\hline \multicolumn{3}{|l|}{ Age (years) } \\
\hline $20-24$ & 6.2 & \\
\hline $25-29$ & 25.8 & \\
\hline $30-34$ & 35.2 & 32.0 years \\
\hline $35-39$ & 32.8 & \\
\hline \multicolumn{3}{|l|}{ Sex } \\
\hline Male & 59.4 & \\
\hline Female & 40.6 & \\
\hline \multicolumn{3}{|l|}{ Marital status } \\
\hline Single & 39.0 & \\
\hline Married & 60.2 & \\
\hline Divorced & 0.8 & \\
\hline separated or widowed & 0 & \\
\hline \multicolumn{3}{|l|}{ Educational level } \\
\hline No formal education & 0.8 & \\
\hline Primary education & 2.3 & \\
\hline Secondary education & 32.8 & \\
\hline Tertiary education & 64.1 & \\
\hline Household Size (persons) & & 4 persons \\
\hline $1-3$ & 47.7 & \\
\hline $4-6$ & 46.1 & \\
\hline $7-10$ & 6.2 & \\
\hline \multicolumn{3}{|l|}{ Parents Occupation } \\
\hline Farming & 50.0 & \\
\hline Civil Servant & 26.6 & \\
\hline Artisan & 8.6 & \\
\hline Years of Farming Experience & & 6.60 years \\
\hline $1-5$ & 50.8 & \\
\hline $6-10$ & 32.8 & \\
\hline $11-15$ & 10.2 & \\
\hline$>15$ & 6.2 & \\
\hline Farm Size (hectares) & & 5.75 ha. \\
\hline$<1$ & 3.9 & \\
\hline $1-5$ & 65.7 & \\
\hline $6-10$ & 8.6 & \\
\hline $11-15$ & 7.0 & \\
\hline$>15$ & 14.8 & \\
\hline Years of Participation & & 3.24 years \\
\hline $1-3$ & 66.4 & \\
\hline $4-6$ & 25.8 & \\
\hline $7-10$ & 7.8 & \\
\hline
\end{tabular}

Source: Field survey, 2014

A larger percentage of respondents $(60.2 \%)$ were married this implies that married youth are more likely to participate in agricultural activities than unmarried ones. This is due to the fact that married persons have more family obligations than unmarried 
Creative commons User License: CC BY-NC-ND

Abstracted by: EBSCOhost, Electronic Journals Service (EJS),

Google Scholar, Directory of Open Access Journals (DOAJ),

Journal Seek, Scientific Commons,

Food and Agricultural Organization (FAO), CABI and Scopus
Journal of Agricultural Extension

Vol. XX (X) XXXXXX, 20XX

ISSN(e): 24086851; ISSN(Print); 1119944X

http://journal.aesonnigeria.org

http://www.ajol.info/index.php/jae

Email: editorinchief@aesonnigeria.org

persons. This corroborates the position of Kimaro, Towo and Benson (2015) that married youth have more socio-economic needs to meet than unmarried ones. A majority (99.2\%) of the youths had one form of formal education. This implies that formal education enhances participation and adoption of modern agricultural technologies and innovations. This agrees with Angba (2003) that participation increases with increased education.

The household size of respondents ranges between 1 and 10 persons. Having a mean of 4 persons, household size between 1 and 3 persons constituted a larger percentage (47.7\%). This implies that most respondents had small household size this is likely due to more education and increase awareness on family planning. Participants whose parents are farmers were $50.0 \%$. This suggests that parents' occupation influenced desires, interests and participation in the programme this is corroborated by Nnadi and Akwiwu (2008) who posits that the background and orientation of the youths is influenced by the occupation of parent's occupation. The mean farming experience was 6.60 , more than half $(50.8 \%)$ of respondents had between 1 and 5 years of farming experiencing, this implies that most respondents are fresh hands in agriculture, which is the aim of the programme to encourage new person to join the agricultural sectors. The mean farm size of respondents was 5.75 hectares; about $65.5 \%$ of participants had farm size between 1 and 5 hectares. This implies that most participants in YIAP were small scale farmers as international standards classify farmers having farms less than 10 hectares as small scale farmers this will influence their participation in YIAP. The mean year of participation in YIAP was 3.24 years; a larger percent (66.4\%) of the participants had between 1 and 3 years, $25.8 \%$ had between 4 and 6 years of participation. This implies that most of the respondents are new entrants into the programme

\section{Attitudes of Participants towards Youth-in-Agriculture Programme}

Results on Table 3 presents respondents' attitude towards YIAP. It revealed that the disposition of the respondents towards the attitudinal statements was in favour of the statements that, YAIP could be a means of introducing new techniques and practices in crop production (3.54); properly organized youth in agriculture programmes may help improve the income of youths (3.52) and active participation in agriculture 
Creative commons User License: CC BY-NC-ND

Abstracted by: EBSCOhost, Electronic Journals Service (EJS), Google Scholar, Directory of Open Access Journals (DOAJ), Journal Seek, Scientific Commons,

Food and Agricultural Organization (FAO), CABI and Scopus
Journal of Agricultural Extension

Vol. XX (X) XXXXXX, 20XX

ISSN(e): 24086851; ISSN(Print); 1119944X

http://journal.aesonnigeria.org

http://www.ajol.info/index.php/jae

Email: editorinchief@aesonnigeria.org

programmes could raise the production efficiency and productivity of the beneficiaries (3.50).

\section{Table 3: Distribution of respondents by attitudes towards YIAP}

\begin{tabular}{|c|c|c|c|}
\hline $\mathbf{S} / \mathbf{N}$ & Attitudinal Statements & Mean & SD \\
\hline 1. & $\begin{array}{l}\text { Youth in agriculture programmes cannot motivate youths to take up } \\
\text { agribusiness. }\end{array}$ & 1.62 & 0.41 \\
\hline 2. & $\begin{array}{l}\text { Youth in agriculture programmes cannot improve the skills of youth in } \\
\text { livestock production, aquaculture and crop production. }\end{array}$ & 1.83 & 0.52 \\
\hline 3. & $\begin{array}{l}\text { Youth in agriculture programmes could be a means of introducing new } \\
\text { techniques and practices in crop production. }\end{array}$ & 3.54 & 0.61 \\
\hline 4. & $\begin{array}{l}\text { Properly organized youth in agriculture programmes may help improve the } \\
\text { income of youths. }\end{array}$ & 3.52 & 0.74 \\
\hline 5. & $\begin{array}{l}\text { Youth in agriculture programmes can help solve the production problems in } \\
\text { agro-processing. }\end{array}$ & 3.20 & 1.0 \\
\hline 6. & Youth in agriculture programmes are for selfish interest of the government. & 1.94 & 0.45 \\
\hline 7. & $\begin{array}{l}\text { Youth in agriculture programme is not meant for youths who cannot secure } \\
\text { good jobs. }\end{array}$ & 1.84 & 0.57 \\
\hline 8. & Government is not committed to agriculture programmes. & 1.95 & 0.53 \\
\hline 9. & $\begin{array}{l}\text { Youth in agriculture programmes cannot bring socio- economic changes on the } \\
\text { youth. }\end{array}$ & 1.73 & 0.69 \\
\hline 10. & Youth in agriculture programmes is not addressing the felt needs of the youth. & 1.87 & 0.71 \\
\hline 11. & Since I have been involve in youth agriculture programme I have no regret. & 3.14 & 1.23 \\
\hline 12. & Youths in agriculture programme would ens & 3.41 & 1.22 \\
\hline 13. & Youth in agriculture programme could improve welfare of the population. & 3.32 & 1.09 \\
\hline 14. & $\begin{array}{l}\text { Youth in agriculture programme is a pre-requisite to effective development in } \\
\text { agricultural sector. }\end{array}$ & 3.26 & 1.02 \\
\hline 15. & $\begin{array}{l}\text { Youth in agricultural programmes does not include all households engaged in } \\
\text { agricultural activities. }\end{array}$ & 2.70 & 0.98 \\
\hline 16. & $\begin{array}{l}\text { Government policies to improve agricultural productivity through agricultural } \\
\text { programmes are not effective. }\end{array}$ & 2.30 & 0.87 \\
\hline 17. & Youth capacity could be enhanced through youth -in-agriculture programmes. & 3.39 & 1.11 \\
\hline 18. & $\begin{array}{l}\text { Participation in youth in agriculture programme is necessary and desirable for } \\
\text { achievement of development objectives. }\end{array}$ & 3.38 & 1.00 \\
\hline 19. & $\begin{array}{l}\text { Active participation in agriculture programmes could raise the production } \\
\text { efficiency and productivity of the beneficiaries. }\end{array}$ & 3.50 & 1.31 \\
\hline 20. & Youth in agriculture programme create rapid employment opportunity. & 3.45 & 1.08 \\
\hline
\end{tabular}

The categorization of respondents' based on attitude towards youth-in-agriculture programme on Table 4 revealed that $68.0 \%$ of respondents had favourable attitude towards the programme while $32.0 \%$ had unfavourable attitude to the programme. This implies that a larger percent of respondents had favourable disposition towards 
Creative commons User License: CC BY-NC-ND

Abstracted by: EBSCOhost, Electronic Journals Service (EJS),

Google Scholar, Directory of Open Access Journals (DOAJ),

Journal Seek, Scientific Commons,

Food and Agricultural Organization (FAO), CABI and Scopus
Journal of Agricultural Extension

Vol. XX (X) XXXXXX, 20XX

ISSN(e): 24086851; ISSN(Print); 1119944X

http://journal.aesonnigeria.org

http://www.ajol.info/index.php/jae

Email: editorinchief@aesonnigeria.org

participation in YIAP. This finding contradicted that of Ovwigho and Ifie (2009) who found that majority of youths had negative attitude towards agricultural programmes.

Table 4: Categorization of respondents by attitude towards participation in YIAP

\begin{tabular}{llllll}
\hline Attitude & Percent & Min. & Max. & $\begin{array}{l}\text { Standard } \\
\text { Deviation }\end{array}$ & Mean \\
\hline Unfavourable & 32.0 & 51.00 & 72.00 & 5.23 & 64.3 \\
Favourable & 68.0 & & & & \\
Total & 100 & & & & \\
\hline
\end{tabular}

Source: Field Survey, 2014

\section{Constraints to participation in Youth-in-Agriculture Programme}

Results on Table 5 revealed that inadequate training facilities were the most severe constraint. This substantiate the finding of Onuekwusi (2005) that Lack of infrastructure and essential input also hinders youth's participation in agricultural and rural development activities. This may be due to inadequate or lack of continuous funding by government; followed by, inadequate credit facilities corroborating the findings of Ouma, De-Groot and Owour (2006) who posit that prominent among problems affecting the use of improved agricultural technologies by farmers is access to credit. While, inadequate extension service was third in order of severity. This is in line with the findings of Aphunu and Atoma (2010) who affirmed that increased agricultural productivity and enhanced farmers income are only attainable when an effective agricultural extension system is put in place.

Table 5: Distribution of respondents by constraints to participation

\begin{tabular}{lllll}
\hline S/N & Constraints & Mean & SD & Rank \\
\hline 1 & Lack of modern agricultural equipment and machinery & 0.78 & 0.23 & $5^{\text {th }}$ \\
2. & Inadequate credit facilities & 0.94 & 0.33 & $2^{\text {nd }}$ \\
3. & Inability to establish links with agricultural programme & 0.60 & 0.29 & $8^{\text {th }}$ \\
& agencies & 0.86 & 0.51 & $3^{\text {rd }}$ \\
4. & Inadequate extension service & 0.57 & 0.40 & $10^{\text {th }}$ \\
5. & Social and psychological effects of being called a farmer & 0.59 & 0.21 & $9^{\text {th }}$ \\
6. & Inaccessability to market & 0.73 & 0.12 & $6^{\text {th }}$ \\
7. & Lack of continuity in agricultural programmes & 0.98 & 0.32 & $1^{\text {st }}$ \\
8. & Inadequate training facilities & 0.80 & 0.21 & $4^{\text {th }}$ \\
9. & Low farming profit margins in agricultural enterprise & 0.69 & 0.11 & $7^{\text {th }}$ \\
10. & Long distance to YIAP site & & & \\
\hline
\end{tabular}

Source: Field survey, 2014 
Creative commons User License: CC BY-NC-ND

Abstracted by: EBSCOhost, Electronic Journals Service (EJS), Google Scholar, Directory of Open Access Journals (DOAJ), Journal Seek, Scientific Commons,

Food and Agricultural Organization (FAO), CABI and Scopus
Journal of Agricultural Extension

Vol. XX (X) XXXXXX, 20XX

ISSN(e): 24086851; ISSN(Print); 1119944X

http://journal.aesonnigeria.org

http://www.ajol.info/index.php/jae

Email: editorinchief@aesonnigeria.org

\section{Participation of Youth-in-agriculture programme}

Table 6 presents distribution of respondents by participation in youth-in-agriculture programme. It reveals that participation was mostly in crop production (1.46), this is in line with the findings of Aphunu and Atoma (2010). Their participation in crop production could be due to early maturity periods of most crops cultivated and possibly because of quick turnover. This is followed by agricultural business (1.35) and piggery (1.34) among other livestock. Participation was low in the area of poultry $(0.75)$, snailery (0.05), and goat rearing (0.52), fishery (0.81) this implies that youths are more involved in crop production than livestock production and other agricultural activities.

Table 6: Distribution of respondents by participation in YIAP

\begin{tabular}{llll}
\hline $\begin{array}{l}\text { Agro-enterprise } \\
\text { involved }\end{array}$ & Mean & SD & Rank \\
\end{tabular}

\begin{tabular}{llll}
\hline Crop production & 1.46 & 0.55 & $1^{\text {st }}$ \\
Agricultural business & 1.35 & 0.54 & $2^{\text {nd }}$ \\
Piggery & 1.34 & 0.30 & $3^{\text {rd }}$ \\
Farm labour & 1.20 & 0.23 & $4^{\text {th }}$ \\
Feed processing & 1.16 & 0.71 & $5^{\text {th }}$ \\
Crop processing & 1.06 & 0.41 & $6^{\text {th }}$ \\
Horticulture & 0.84 & 0.10 & $7^{\text {th }}$ \\
Fishery & 0.81 & 0.21 & $8^{\text {th }}$ \\
Poultry & 0.75 & 0.29 & $9^{\text {th }}$ \\
Farm maintenance & 0.68 & 0.11 & $10^{\text {th }}$ \\
Goat rearing & 0.52 & 0.09 & $11^{\text {th }}$ \\
Snailery & 0.05 & 0.01 & $12^{\text {th }}$ \\
\hline Source: Fid survey & 2014 & &
\end{tabular}

\section{Source: Field survey, 2014}

Results on Table 7 reveals that participation in youth-in-agriculture programme was high $(57.0 \%)$, this may be due to their favourable disposition towards the programme. This suggests that the programme is more likely to be sustainability as participation in development project has been found to enhance sustainability (Ataneh, 2012). 
Creative commons User License: CC BY-NC-ND

Abstracted by: EBSCOhost, Electronic Journals Service (EJS),

Google Scholar, Directory of Open Access Journals (DOAJ),

Journal Seek, Scientific Commons,

Food and Agricultural Organization (FAO), CABI and Scopus
Journal of Agricultural Extension

Vol. XX (X) XXXXXX, 20XX

ISSN(e): 24086851; ISSN(Print); 1119944X

http://journal.aesonnigeria.org

http://www.ajol.info/index.php/jae

Email: editorinchief@aesonnigeria.org

Table 7: Categorisation of respondents based participation in YIAP

\begin{tabular}{llllll}
\hline $\begin{array}{l}\text { Level of } \\
\text { participation }\end{array}$ & Percentage & Min. & Max. & Mean & $\begin{array}{l}\text { Standard } \\
\text { Deviation }\end{array}$ \\
\hline Low & 43.0 & 1.00 & 21.00 & 11.22 & 4.16 \\
High & 57.0 & & & & \\
Total & 100 & & & & \\
\hline
\end{tabular}

Source: Field Survey, 2014

Relationship between the selected socioeconomic characteristics and participation in YIAP

Tables 8 and 9 revealed that there was significant relationship between household size $(r=0.291, P \leq 0.05)$ years of farming experience $(r=0.532 P \leq 0.05)$ and participation in YIAP. This implies that the higher the household size and farm size, the higher their participation in YIAP. This suggests that farming experience could enhance participation in the agricultural programmes in order to improve their skills. Also, significant relationship exists between $\operatorname{sex}\left(X^{2}=7.747, P \leq 0.05\right)$ and participation in YIAP. This is because a higher percentage of respondents were males. This corroborates Nxumalo and Oladele (2013) who posit that male farmers are more likely to participate in agricultural programme because of their access and control over resources.

Table 8: Correlation between selected socioeconomic characteristics and participation in YIAP

\begin{tabular}{lcc}
\hline Variables & $\mathbf{R}$ & $\mathbf{P}$ \\
\hline Age & 0.110 & 0.218 \\
Household size & 0.291 & $0.001^{*}$ \\
Years of farming experience & 0.532 & $0.020^{*}$ \\
Farm size & 0.148 & 0.096 \\
\hline${ }^{*} \mathrm{P} \leq 0.05$ & &
\end{tabular}

Table 9: Chi-square analysis between selected socioeconomic characteristics and participation in YIAP

\begin{tabular}{|c|c|c|c|}
\hline Variable & $x^{2}$ & df & $\mathbf{P}$ \\
\hline Sex & 7.747 & 1 & $0.005^{\star}$ \\
\hline Marital status & 1.347 & 2 & 0.510 \\
\hline Level of education & 1.444 & 3 & 0.695 \\
\hline Parent's occupation & 4.860 & 3 & 0.182 \\
\hline
\end{tabular}

${ }^{*} \mathrm{P} \leq 0.05$ 
Creative commons User License: CC BY-NC-ND

Abstracted by: EBSCOhost, Electronic Journals Service (EJS), Google Scholar, Directory of Open Access Journals (DOAJ), Journal Seek, Scientific Commons

Food and Agricultural Organization (FAO), CABI and Scopus
Journal of Agricultural Extension

Vol. XX (X) XXXXXX, 20XX

ISSN(e): 24086851; ISSN(Print); 1119944X

http://journal.aesonnigeria.org

http://www.ajol.info/index.php/jae

Email: editorinchief@aesonnigeria.org

\section{Determinants of youth participation in YIAP}

Multiple linear regression analysis was used to determine youths' participation in YIAP in the study area. The results from the multiple regression in Table 10 revealed that significant to participation in YIAP were household size $(\beta=0.133)$, farm size ( $\beta$ $=0.373)$, years of participation in YIAP $(\beta=0.354)$, attitude $(\beta=0.228)$ and constraints $(\beta=-0.074)$. The results show that while there are positive (direct) relationships between household size, farm size, years of participation and attitude, constraints was inversely related to participation. The result also reveals that the $\mathrm{R}^{2}$ value is 0.228 this indicates that the independent variables in the regression model explain $22.8 \%$ of contribution to the dependent variable. Farm size is a main predictor of participation in YIAP this corroborates Agbonlahor, Oluwafemi, Sodiaya, Oludare, and Oke (2012) who found that farm size significantly influenced the intensity of participation of co-operative members in the participation in off-farm activities. Years of participation in YIAP contributes mostly to participation. The sign for each coefficient is consistent with the expectation; that is, the probability of Youths' participation in agricultural programme increases if farm size and years of participation increase. Likewise, a positive disposition or attitude towards the programme would translate to high level of participation and the more constraints faced by youths, the lesser their participation in YIAP.

Table 10: Determinants of youth participation in youth-in-agriculture programme

\begin{tabular}{lrrr}
\hline Explanatory variable & Standardized error & $\beta$-value & T-value \\
\hline (Constant) & 4.261 & & 2.439 \\
Age & 0.095 & 0.118 & 1.094 \\
Sex & 0.715 & 0.168 & 1.980 \\
Marital status & 0.855 & 0.058 & 0.555 \\
Level of education & 0.661 & 0.050 & 0.543 \\
Household size & 0.191 & 0.195 & $2.167^{*}$ \\
Parents occupation & 0.340 & 0.082 & 0.922 \\
Years of farming experience & 0.085 & 0.067 & 0.661 \\
Farm size & 0.077 & 0.403 & $3.482^{*}$ \\
Years of participation in YIAP & 0.234 & 0.363 & $3.231^{*}$ \\
Member of youth association & 0.865 & 0.069 & 0.845 \\
Attitude & 0.068 & 0.228 & $2.784^{*}$ \\
Constraints & 0.066 & -0.074 & $-0.860^{*}$ \\
\hline
\end{tabular}

${ }^{*} \mathrm{P} \leq 0.05$

$R^{2}=0.307$, adjusted $R^{2}=0.228,{ }^{*} p \leq 0.05$ 
Creative commons User License: CC BY-NC-ND

Abstracted by: EBSCOhost, Electronic Journals Service (EJS),

Google Scholar, Directory of Open Access Journals (DOAJ),

Journal Seek, Scientific Commons,

Food and Agricultural Organization (FAO), CABI and Scopus
Journal of Agricultural Extension

Vol. XX (X) XXXXXX, 20XX

ISSN(e): 24086851; ISSN(Print); 1119944X

http://journal.aesonnigeria.org

http://www.ajol.info/index.php/jae

Email: editorinchief@aesonnigeria.org

\section{Conclusion and Recommendation}

The study concludes that farm size and years of participation mostly contributed to participation in YIAP. There was high participation in YIAP, youths have favourable attitude towards the programme andinadequate training facilitieswas the most severe constraint. It therefore recommends increased effort by relevant agencies in providing extension education, encouraging female youth participation and harnessing youth involvement in agriculture programme will ultimately reduce ruralurban drift.

\section{References}

Agbonlahor, M. U., Oluwafemi, S. E., Sodiaya, C. I., Oludare, A., and Oke, J. T. (2012). Accelerating Rural Growth Through Collective Action: Groups' Activities and Determinants of Participation in South-Eastern Nigeria, Journal of Rural Social Sciences, 27(1): Pp. 114-136.

Angba, A.O., (2003). Effect of rural urban migration of youths on agricultural supply in Umuahia North local government area of Abia State, Nigeria. Journal of Agriculture and Social Research. 3(5): Pp. 77-83.

Aphunu, A. and Atoma, C.N. (2010). Rural Youth Involvement in Agricultural Production in Delta Central Agricultural Zone: Challenge to Agricultural Extension Development in Delta State. Journal of Agricultural Extension 14 (2): Pp. $46-47$

Ataneh, O. S. (2012). Participation of Members of Youth Association In Rural Community Development in Edo State Nigeria. Unpublished M.Sc Project. Department of Agricultural Extension and Rural Development, University of Ibadan, Ibadan.

Kimaro, P. J., Towo, N. N. and Benson H. M. (2015). Determinants of rural youth's participation in agricultural activities: the case of Kahe East ward in Moshi rural district, Tanzania. International Journal of Economics, Commerce and Management. Vol. 3(2): pp. 33

Ministry of Agriculture (2007). National Agricultural Extension Policy Implementation Framework. Nairobi, FAO.

Muhammad-Lawal, A., Omotosho, O. A. and Falola, A. (2009). Technical efficiency of youth participation in agriculture: A case study of youth - in - Agriculture Programme in Ondo State, south western Nigeria. Nigeria Journal of Agriculture, food and Environment, 5(1): Pp. 20- 26

Nnadi F. N and Akwiwu C. D. (2008). Determinants of Youths' Participation in Rural Agriculture in Imo State, Nigeria. Journal of Applied Sciences, 8(5): Pp. $\underline{328-333}$ 
Creative commons User License: CC BY-NC-ND

Abstracted by: EBSCOhost, Electronic Journals Service (EJS),

Google Scholar, Directory of Open Access Journals (DOAJ),

Journal Seek, Scientific Commons,

Food and Agricultural Organization (FAO), CABI and Scopus

\author{
Journal of Agricultural Extension \\ Vol. XX (X) XXXXXX, 20XX \\ ISSN(e): 24086851; ISSN(Print); 1119944X \\ http://journal.aesonnigeria.org \\ http://www.ajol.info/index.php/jae \\ Email: editorinchief@aesonnigeria.org
}

Nxumalo, K. K. S., and Oladele O. I (2013).“Factors Affecting Farmers' Participation in Agricultural Programme in Zululand District, Kwazulu Natal Province, South Africa". Journal of Social Science 34(1): Pp. 83-88

Ogunremi, O. O., Ogunremi, J. B. and Faleyimu, O. I. (2012). Relevance and benefits of agricultural youth empowerment programme to participating youth in Osun state, Nigeria. Asian journal of social sciences \& humanities. 1(2): Pp. 7 19

Onuekwusi, G. C. (2005). Youth Programme in Extension and Rural Development: Agricultural Extension and Rural Sociology. Snaap Press, Enugu. pp 191-214

Ouma, J. O., De-Groot, H. and Owour, O. (2006). Determinants of Improved Maize Seed and Fertilizer Use in Kenya: Policy Implications. Paper presented at the International Association of Agricultural Economists' Conference, Gold Coast, Australia

Ovwigho, B. O. and Ifie, P. A. (2009). Attitude of Youth towards Aricultural Development Programmes in Ughelli South Local Government Area of Delta State, Nigeria. Journal of Agricultural Extension 13(2): Pp. 67-69

Preshstore (2013). Improving Agricultural Production Through Agricultural Cooperatives. Retrieved from https://preshstore/status/.com on $27^{\text {th }}$ July 2015 